\title{
Access to bank credit by smallholder farmers in Tanzania: a case study
}

\author{
Nsubili Isaga \\ School of Business, Mzumbe University, Tanzania
}

\begin{abstract}
Tanzania like many other developing countries is highly dependent on agriculture for income generation and job creation for its citizens. Because the sector is mainly composed of smallholder farmers, lack of finance remains the leading obstacle to development. This study seeks to determine factors that affect access to bank credit by smallholder farmers in the Mvomero District of Morogoro, Tanzania. The study used a cross-sectional design, with data being collected via the survey method. Purposeful sampling was used to obtain the respondents who fitted into the study objective. The data were analyzed using descriptive statistics and a logistic regression model. The Logit regression model in particular was employed to determine factors that affect smallholder farmers' access to bank services. The study reveals that the value of assets invested in farming activities, education and gender are significant factors affecting smallholder farmers' access to bank credit. Policy recommendations include the establishment of a government bank that would exclusively provide financial services to agriculturalists by establishing a credit guarantee scheme, and the development of new financial products by the banks that would cater to the needs of smallholder farmers.
\end{abstract}

Key words: access, bank credit, smallholder farmers, logit regression

\section{Introduction}

The agricultural sector is recognized as a driving force of income generation and job creation, and the backbone of many economies as it continues to play a vital role in economic growth and sustainable development (Bee, 2007; Miller et al., 2010; Salami et al., 20II; World Bank, 2013). In addition to being a significant source of economic growth especially in developing countries, it is widely acknowledged that the development of the agricultural sector is an effective instrument to alleviate poverty and enhance food security (Louw et al., 2008; Miller et al., 2010). 
Tanzania is one of many developing countries that depend on agriculture in terms of income generation and job creation. In 2012, it was reported that the sector employed more than $80 \%$ of the Tanzanian population, contributing an estimated $28 \%$ to the Gross Domestic Product (GDP) and constituting 30\% of export earnings (Salami et al., 20II; InfoDev, 2012). The production or manufacturing stage in the agriculture sector in Tanzania and Africa as a whole is mainly composed of smallholder farmers. According to MAFAP (2013), the role of agriculture in providing employment in Tanzania is forecast to remain close to $50 \%$ until 2025 .

Like many other developing countries, Tanzania has recognised the importance of its agricultural sector for economic development and poverty alleviation. Accordingly, the Tanzanian government has introduced various policies and programmes to boost the development of the sector. At a national level, the Agricultural Sector Development Strategy (ASDS) and the National Strategy for Growth, Reduction of Poverty (NSGRP), National Microfinance Policy (2000) and National Trade Policy (2003) were established to boost development. According to MAFAP (2013), among the policies formulated under the producer-oriented policies is access to credit, for which the government disbursed 22 billion Tanzanian Shilling (Tshs 22 billion) to the Tanzania Investment Bank to provide financing for agriculture financing. The loan facility supports the procurement of tractors, small hand-operated power tillers, irrigation equipment, livestock, commercial vehicles, tractor-trailers, storage equipment and other farm implements. Furthermore, the Government commenced the new Kilimo Kwanza (Agriculture First) as Tanzania's Green Revolution strategy aimed at modernising and commercialising agriculture (Mbunda, 20II).

Unfortunately, despite the existence of various programmes, a number of challenges still hinder productivity and growth in the sector, with lack of finance cited as the leading obstacle. As smallholder farmers make up the bulk of the sector, the lack of access to financial services has a detrimental effect on their farming activities and performance (Bee, 2007; Miller et al., 20Io; Salami et al., 20II; World Bank, 2013). To boost agricultural production and productivity, smallholder farmers need to use improved agricultural technologies. However, the adoption of these technologies is relatively expensive and smallholder farmers cannot afford to self-finance the use of these new technologies. Therefore, enhanced provision of credit to rural farmers would accelerate agricultural production and productivity. While commercial institutions, particularly banks, are the major suppliers of finance to business enterprises and the agricultural sector in other countries, this is not the case in Tanzania. Bee (2007) found that $32 \%$ of business financing came from informal sources; $33 \%$ from rotating savings and credit association; $19 \%$ from savings and credit co-operative societies; and $16 \%$ from commercial financing institutions. According to Salami et al., (20II) commercial bank loans to agriculture have been provided at a low level compared to loans issued to manufacturing, trade, and other service sectors. This is hampering expansion and technology adoption. The poor or lower income groups are usually excluded from credit facilities for various reasons, including: insufficient collateral to support their loans, high transaction costs, unstable income, poor credit history as well as inadequate accounting records, low levels of literacy and high monitoring costs 
(Nawai \& Shariff, 20I0). Thus, in addition to their own resources, smallholder farmers rely on income boosted by loans from friends and relatives, remittances, and informal money lenders (Salami et al., 20II). As a result, $48 \%$ of people involved in Tanzanian agribusiness self-finance their activities (InfoDev, 2012). Commercial banks and/or development banks are out of reach for poor smallholder farmers and even when formal banks provide credit, it is directed to specific production activities regardless of the area of demand (Auma and Mensah, 20I4). Commercial financing institutions consider agriculture a high-risk venture due to unpredictable weather and political interference. In addition, the agricultural sector is constrained by inadequate infrastructure, the challenge of reaching customers and limited products that may be unsuitable for agro-processing growth enterprises (InfoDev, 20I2). According to Wolter (20I0), financial institutions have a negative perception of lending with the intent to facilitate agricultural activities, a view that helps to explain the small number of banks in rural areas. Only $3 \%$ of agricultural households have access to credit.

It is difficult to overstate the importance of credit in the agricultural economy, especially since it has been put forward as a tool for agricultural development. Credit for smallholder farmers is gaining relevance in many parts of the world in response to the needs of less privileged entrepreneurs with limited capital base in the sector (Obisesan, 20I3). Unfortunately, several factors are thought to limit smallholder farmers' access to credit (Dzadze et al., 20I2). Few studies (if any) in Tanzania have addressed the means of improving access to finance in the agricultural sector. Therefore, this study seeks to identify the factors that affect smallholder farmers' access to bank credit in the Mvomero District of Morogoro, Tanzania.

This paper is sub-divided into four sections. The literature review is followed by the methodology section, which describes and explains the tools employed for data collection. This is followed by a presentation and discussion of the findings of the study. The summary and conclusion highlights the key findings after which the recommendations are presented.

\section{Literature review}

Smallholder farming involves producing agricultural yields on relatively small plots of land. Smallholder farmers cultivate less than five hectares of land predominantly located in rural provinces (Jari, 2009). Smallholder farming in Tanzania involves agricultural activities such fiber (sisal and cotton), beverages (coffee and tea), sugarcanes, grains (a diverse range of cereals and legumes), horticulture (temperate and tropical fruits, vegetables and flowers) and edible oils (InfoDev, 2012).

Despite the number of challenges facing the sector, including access to finance, the agricultural sector as well as the agribusiness sector has continually been cited as the driving force for income generation, job creation, and as the backbone of most economies (Miller et al., 20I0; Salami et al., 20II; World Bank, 20I3). According to MAFAP (2013), the sectors' role in providing employment in Tanzania is forecast to remain close to $50 \%$ until 2025. Therefore, easing the sectors' access to finance can result in a range of bene- 
fits: an increase in employment levels and consequently increased income generation for the vast majority of people, poverty alleviation and enhanced food security. Kimathi et al., (2008) state that enhanced access to finance triggers the generation of real income that increase substantially across poor communities, value chain players and market players.

\section{Obstacles to smallholder farmers financing}

Smallholder farmers still encounter a number of challenges that hinder their agricultural productivity and growth. To mention a few, the key long-standing challenges are low productivity stemming from the lack of access to markets and technology; inadequate sustainability of product grades, standards and quality in agricultural product marketing; weak legal and regulatory framework regarding agricultural marketing; inadequate market research, and above all, a lack of access to formal financial services from the manufacturing stage, processing, and all the way to the marketing stage (Salami et al., 20II; URT, 2008).

It is not only farmers or agribusiness entrepreneurs who experience difficulties in accessing finance, but also banks as major suppliers of finance face various challenges in providing the same to agribusiness enterprises. According to the World Bank (2013), unfavourable interest rates, complex application procedures, information asymmetries and high collateral requirements are among the major challenges arising from both the demand and supply factors. Collateral requirements by commercial banks in developing countries have been a contentious issue in SME financing particularly in the agribusiness sector (Wattanapruttipaisan, 2003). In some cases, commercial banks may deem the collateral insufficient in view of the size of the loan requested. In other words, the proposed expansion project may be too large in comparison with the current size of the firm (OECD, 2004). Banks also have insufficient asymmetric information as they have difficulty in assessing the creditworthiness of agribusiness entrepreneurs, especially those located in remote areas (OECD, 2004). Agribusiness entrepreneurs are said to lack credit history and accounting reports, which can be used by banks to assess their credit worthiness. As a result, banks tend to require more collateral and to set higher interest rates to compensate for these risks (Wattanapruttipaisan, 2003; Coates et al., 20II; OECD, 2013; MAFAP, 2013;). Underdeveloped legal systems prevent the development of certain financing instruments, including the use of collateral as a risk-mitigating element. However, even when adequate legislation is available, there are often problems with enforcement. There are lengthy procedures for filing mortgages, pledges and ascertaining the status of particular assets. There are also often cases of corruption among personnel (OECD, 2006).

Coates et al., (20II) point to distant dysfunctional markets, inadequate farming and inappropriate techniques, volatile prices and unpredictable weather as among the issues impeding lenders and farmers towards easing accessibility of finance. These factors lead to lower quality of produce by enterprises. Lower quality output and profit is realized by SMEs due to higher transaction costs for lenders, making banks more reluctant to lend to them (OECD, 2013). 
Factors affecting access to bank credit by smallholder farmers

Access to bank credit is significantly influenced by collateral requirement as it reduces the bank's risk exposure, particularly default risk, and also demonstrates the borrowers' good faith (Yehuala 2008; Gaisina 2010 and OECD 2013). According to Chauke et al., (2013) and Yehuala (2008) the distance between lender and borrower is an important factor in terms of influencing access to credit for smallholder farmers. Smallholder farmers who reside in rural areas are less likely to borrow from formal financial institutions, which are located in town centers. In addition to the distance issue, Obisesan (2013) reported gender as among the factors which were found to affect the smallholder farmers' access to bank credit. This is consistent with Yehuala (2008) who found that credit access for female-headed households is limited. However, it contradicts research conducted by Akudungu (2012) which found that women are more likely to demand credit than men in the Upper East Region of Ghana. The habit of saving significantly influences the smallholder farmer's access to credit as it acts as a form of economic security for the farm household and provides formal financial institutions with a financial history on which they can base lending decisions (Morris and Meyer, I993; Dzadze et al., 2012;)

Education is another factor which is reported to have a significant positive influence on farmers' access to formal credit. For instance Dzadze et al., (2012) reported that a higher level of education is associated with a greater ability to access and comprehend information on credit terms and conditions, and the ability to complete loan application forms properly.

Using the bivariate probit model to predict the probability that corporate farms have received credit from commercial banks, Gaisina (2010) found that the size of a farm is among the main determinants that predict whether an agricultural enterprise can be given credit. This finding corresponds with Yehuala (2008) and Sekyi et al., (2017) who reported the accessibility of credit for smallholder farmers is likely to increase with the increase in the total cultivated land size. Moreover, Gaisina (2010) found that a farm's productivity is also among the main determinants that predict whether an agricultural enterprise can be given credit. The farm's productivity shows the ability of the farmer to generate revenue to cover the principal repayment as well as the interest charges. Chauke et al., (2013) found that the total value of assets invested by farmers in farming activities is the principal factor which positively influences the farmers' access to formal credit. Furthermore, Chauke et al., (2013) identify other factors that contributed significantly to credit access: the need for credit, attitude towards risk, perception of loan repayment and perception of lending procedures. This corresponds to the OECD (20I3) which also reported that borrowers are less likely to have access to credit in the presence of financial institutions' complex application procedures. 


\section{Methodology}

This study was conducted in the Mvomero District situated in Morogoro, Tanzania. Mvomero is located in the northeast Morogoro region between latitudes $8^{\circ} \mathrm{Oo} "$ and $10^{\circ}$ oo" south of the equator and between longitudes $37^{\circ} \mathrm{Oo}$ " and $28^{\circ} 22^{\prime \prime}$ east of Greenwich (URT, 2008). The altitude of the district is between 380 meters and I, 520 meters above sea level thus providing a suitable climate for tropical and subtropical varieties of crops (URT, 2008). The population is about 260,525 people as per 2002 population census. The district's economy depends on agriculture mainly in the form of crop production. The main crops grown are cassava, rice, maize, sugarcane and bananas. With exception of a few paddy and sugar cane fields, cultivation is carried out mainly by use of hand hoe, using primarily family labour and hired labour when the situation demands (URT, 2008).

The study used a cross-sectional design, with data being collected via the survey method. Non probability sampling, namely purposeful sampling was used to obtain the respondents who fitted into the study objective. Non probability sampling was used because of the unavailability of the sampling framework. A survey instrument was developed to capture the information relating to the research objectives. A structured questionnaire was prepared in English and translated into Swahili. Subsequently, a pilot test of the questionnaire was done on a sample of Io people to determine whether the questions were easy to understand and to answer, and to test the reliability and validity of each question in capturing the information desired. The data collection process took place between July and December 20I6. Ultimately, 162 smallholder farmers participated in the fieldwork study.

The specific predictor variables that were examined in this study included gender, marital status, education, total value of assets, farming experience, farm size, income, collateral, interest rate, procedures and proximity. These variables have been frequently mentioned to be factors, which affect smallholder farmers' access to bank credit (Chauke et al., 20I3). The dependent variable is access to bank credit that is a dummy variable equal to one if the smallholder farmers had access to credit and was zero otherwise. Based on the existing literature the following independent variables were identified and their descriptions are listed in Table I. 


\begin{tabular}{|c|c|c|}
\hline $\mathrm{S} / \mathrm{N}$ & Variable & Indicator \\
\hline $\mathbf{I}$ & Gender & Sex of the smallholder farmer Female o, Male I \\
\hline 2 & Marital Status & Marriage standing of the smallholder farmer \\
\hline 3 & Education & Level of formal education of the smallholder farmer \\
\hline 4 & Total value of Assets & Value of assets invested in farming activities \\
\hline 5 & Farming Experience & $\begin{array}{l}\text { Number of years the smallholder farmer engaged in farming } \\
\text { activities }\end{array}$ \\
\hline 6 & Farm size & Number of Acres owned by the smallholder farmer \\
\hline 7 & Income & Income from farming activities \\
\hline 8 & Collateral & Available assets to guarantee the loan \\
\hline 9 & Interest rate & Interest charged \\
\hline I0 & Procedures & Processes involved to obtain a loan \\
\hline II & Proximity & Distance from a bank (Measured in KM) \\
\hline
\end{tabular}

Table 1: Description of independent variables.

\section{Data analysis}

The main aim of the analysis was to determine the factors influencing access to bank credit by smallholder farmers in the Mvomero District. The data analysis involved four main phases: data preparation, descriptive analysis, correlation analysis and logit regression. Data preparation was undertaken soon after completion of the fieldwork: responses from 162 questionnaires were entered into the computer using SPSS software. Thereafter, descriptive analysis, correlation analysis, and logit regression were performed. Due to the nature of the variables, particularly the dependent variable, the logistic regression model was employed to assess how well a set of independent variables determines the access to bank credit by smallholder farmers. This model is similar to a linear regression model but it is suited to models where the dependent variable is dichotomous (Obisesan, 20I3). In this study, the dependent variable was a dummy variable which was equal to one if the smallholder farmers had access to credit and was zero otherwise. According to Yehuala (2008), logistic distribution (logit) enjoys advantage over other regression techniques in the analysis of dichotomous outcome variable in that it is extremely flexible and an easy to use model from a mathematical point of view and the results can be interpreted in a meaningful way. The logistic regression coefficient can be used to estimate odds ratios for each independent variable in the model. The term "logit" refers to the natural logarithm of the odds (log odds) which indicates the probability of falling into one of the two categories on some variable of interest (Chauke et al., 2013). 
The generic form of the logit model as presented by Dzadze et al., (2012) is as follows:

Where

$$
\operatorname{Logit} \mathrm{P}(\mathrm{Y})=\beta_{\mathrm{o}}+\Sigma \beta_{\mathrm{i}} \mathrm{X}_{\mathrm{i}}+\mu
$$

$\mathrm{Y}_{\mathrm{i}}=\mathrm{I}$ if success i.e. respondent has access to credit. and

$\mathrm{Y}_{\mathrm{i}}=\mathrm{o}$ if failure i.e. if respondent did not have access to credit

$\mathrm{X}_{\mathrm{i}}=$ independent variable

$\beta_{\mathrm{o}} \beta_{\mathrm{i}}=$ logistic coefficient for independent variable

$\mu=$ error term

The logistic regression in this study can be specified as:

$$
\begin{gathered}
\mathrm{Y}=\beta_{0}+\beta_{\mathrm{i}}(\mathrm{GNDR})+\beta_{3}(\mathrm{MRTST})+\beta_{4}(\mathrm{EDUC})+\beta_{5}(\mathrm{TVAST})+\beta_{6}(\mathrm{INCM})+ \\
\beta_{7}(\mathrm{OTRCH})+\beta_{9}(\mathrm{XPRNC})+\beta_{\mathrm{Io}}(\mathrm{SCRTY})+\beta_{11}(\mathrm{INRST})+\beta_{12}(\mathrm{PRCDR})+\beta_{13}(\mathrm{FRMSZ})+\mu
\end{gathered}
$$

Whereas:

$\mathrm{Y}=$ ("I" if respondent has access to bank credit and "O" if respondent has no access to bank credit);

$\beta_{0}=$ Constant term;

GNDR $=$ Gender $(\mathrm{I}$ if male, $\mathrm{o}$ if female);

MRTST = Marital Status;

EDUC = Educational Level;

TVAST $=$ Total Value of Assets;

INCM = Income Level;

OTRCH = Bank Outreach;

XPRNC = Farming Experience;

SCTRY = Collateral Security;

INRST = Interest on principal amount;

PRCDR = Procedures;

FRMSZ = Farm Size;

$\boldsymbol{\beta}_{\mathrm{i}}=$ Logistic coefficients for the independent variables;

$\mu=$ Error term

\section{Correlation analysis}

Before logit regression was conducted, correlations among variables were examined. Table 2 provides the results from the correlation analysis. An inspection of the correlation matrix reveals that the majority of the correlations are significant at 0.05 , which provides a strong basis for proceeding. Furthermore, collinearity diagnosis was performed to check the presence of multicollinearity by examining the tolerance and the VIF value. Therefore, from Table 3 it can be concluded that there was no high inter-correlations among the independent variables, because no extraordinarily high coefficients that measure different concepts are reported (Hair et al., 2006; Pallant, 20Io). 


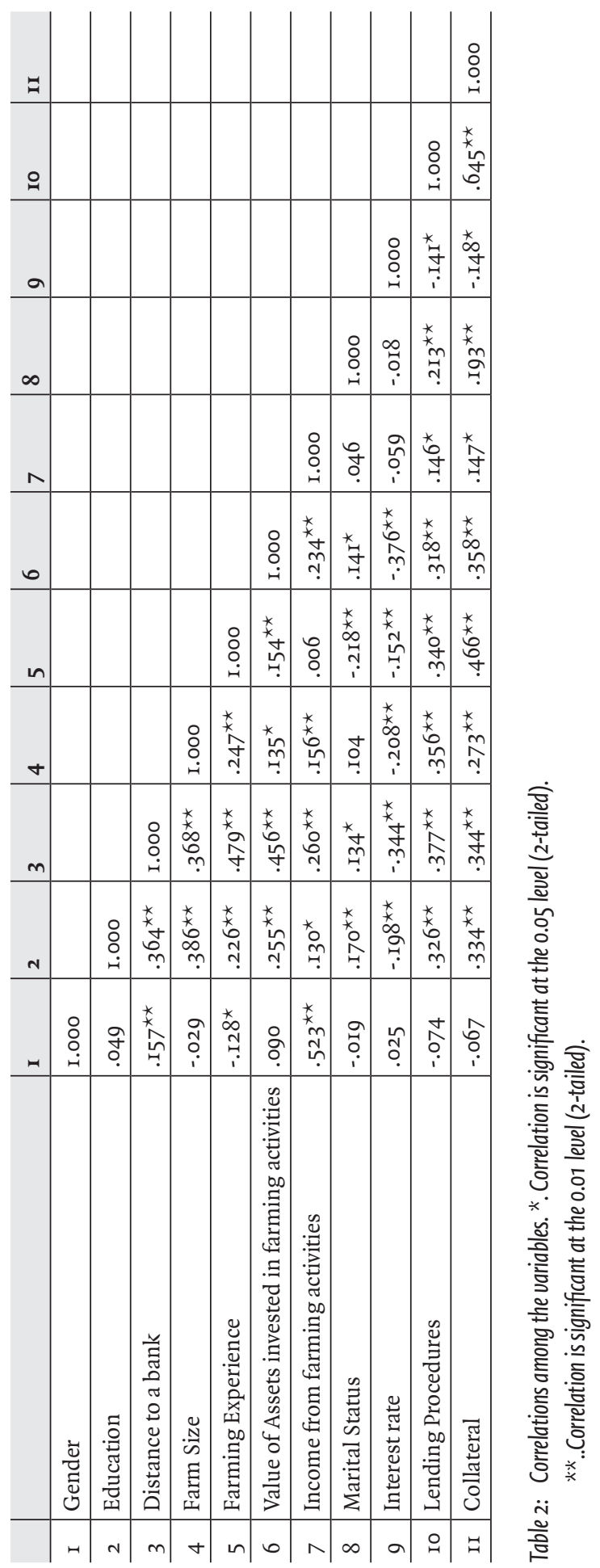




\begin{tabular}{|c|c|c|}
\hline \multicolumn{3}{|l|}{ Coefficients $^{\mathrm{a}}$} \\
\hline & \multicolumn{2}{|c|}{ Collinearity Statistics } \\
\hline & Tolerance & VIF \\
\hline \multicolumn{3}{|l|}{ (Constant) } \\
\hline Gender & 0.820 & I.219 \\
\hline Education & 0.539 & I. 854 \\
\hline Marital Status & $0.75 \mathrm{I}$ & I. $33 \mathrm{I}$ \\
\hline Distance to a bank [Proximity] & 0.830 & $\mathrm{I} .204$ \\
\hline Interest rate & 0.787 & I.27I \\
\hline Farm size in acres & 0.712 & I.405 \\
\hline Farming experience in years & 0.720 & I. 389 \\
\hline Value of assets invested in farming activities & 0.480 & 2.082 \\
\hline Income from Farming Activities & 0.409 & 2.443 \\
\hline Lending Procedures [Procedures] & 0.769 & 1.300 \\
\hline Collateral & 0.865 & I.I55 \\
\hline
\end{tabular}

a. Dependent Variable: Access to Bank Credit

Table 3: Collinearity Diagnostics.

\section{Results and discussion}

Data was collected from 162 smallholder farmers in Mvomero District. It was found that given the sample, $48.8 \%$ of smallholder farmers finance their farming activities using internal funds, I4.2\% borrowed from friends/relatives and I.9\% secured bank loans. These findings are consistent with similar discoveries made by InfoDev (2012) who reported that $48 \%$ of the investment structure of agriculture in Tanzania is derived from internally available funds, $\mathrm{I} 4 \%$ from family/ relatives and $4 \%$ from banks.

Of the 162 smallholder farmers involved in this study, only 14 or $8.6 \%$ of the total sample had access to bank credit. These findings support similar findings made by Mukiri (2008) who upon examining the determinants of access to bank credit by micro and small enterprises in Kenya found that out of 2I8 small manufacturing enterprises in Nairobi, only $8 \%$ had access to bank credit. 


\begin{tabular}{|c|c|c|c|}
\hline & Items & $\mathbf{n}$ & $\%$ \\
\hline \multirow[t]{2}{*}{ Gender } & Female & 102 & 63.0 \\
\hline & Male & 60 & 37.0 \\
\hline \multirow[t]{4}{*}{ Age } & I8-35 & $6 \mathrm{I}$ & 37.65 \\
\hline & $36-45$ & 57 & 35.2 \\
\hline & $46-60$ & 32 & I9.8 \\
\hline & Above 60 & 12 & 7.4 \\
\hline \multirow[t]{6}{*}{ Marital status } & Single & $4 \mathrm{I}$ & $25 \cdot 3$ \\
\hline & Married & III & 68.5 \\
\hline & In relationship & 3 & I.9 \\
\hline & Separated & $\mathrm{I}$ & 0.6 \\
\hline & Widow & 4 & 2.5 \\
\hline & Divorced & 2 & $\mathrm{I} .2$ \\
\hline \multirow[t]{5}{*}{ Education } & Never attended school & 17 & I0.5 \\
\hline & Primary school & 94 & 58.0 \\
\hline & Secondary education & 43 & 26.5 \\
\hline & Diploma & 3 & I.9 \\
\hline & Bachelor Degree & 5 & 3.1 \\
\hline \multirow[t]{4}{*}{ Distance to the Bank } & Very far & 47 & 29.0 \\
\hline & Far & 47 & 29.0 \\
\hline & Near & 19 & II.7 \\
\hline & Very Near & 49 & 30.2 \\
\hline \multirow[t]{5}{*}{ Farm size in Acres } & Below 0.5 & 35 & 21.6 \\
\hline & $0.5-2$ & $8 \mathrm{I}$ & 50.0 \\
\hline & 2.I-5 & 36 & 22.2 \\
\hline & 5.I-IO & 8 & 4.9 \\
\hline & IO.I-20 & $\mathrm{I}$ & 0.6 \\
\hline \multirow[t]{3}{*}{ Purpose of Farming } & Food & 74 & $45 \cdot 7$ \\
\hline & Commercial & I4 & 8.6 \\
\hline & Food and commercial & 74 & $45 \cdot 7$ \\
\hline \multirow[t]{4}{*}{ Farming experience } & $0-5$ & 90 & 55.6 \\
\hline & 6-10 & 46 & 28.4 \\
\hline & II -20 & I4 & 8.6 \\
\hline & Above 20 & 6 & 3.7 \\
\hline \multirow[t]{5}{*}{ Value of assets invested } & Below 500,000 & Iо6 & 65.4 \\
\hline & 500,000-I Million & 34 & $2 \mathrm{I}$ \\
\hline & $\mathrm{I}-3$ Million & $\mathrm{I} 4$ & 8.6 \\
\hline & 3-5 Million & 6 & 3.7 \\
\hline & 5-ro Million & 2 & $\mathrm{I} .2$ \\
\hline
\end{tabular}

Table 4: Characteristics of the respondents $(n=162)$. 
Logit regression analysis was carried out to estimate the logit model. Table 5 shows the final model regression results including the logistic regression coefficient, Wald Test, level of significance and odds ratios for the variables in the equation (Exp (BI). According to the results, three independent variables namely, value of assets invested in farming activities, education and gender had significant influence on the probability of a firm having access to bank credit.

Value of assets invested in farming activities was found to correspond positively to access to bank credit. This suggests that smallholder farmers who have invested more assets in their farming activities are more likely to be able to access bank credit. The greater the value of assets invested in farming activities the greater the capability of smallholder farmers to produce reliable outputs that in turn generate adequate cash flows to repay the debt. It also suggests the availability of security and secondary repayment sources of the loan. These findings are consistent with those of Chauke et al., (2013) who ascertained that value of assets was one of the six factors that significantly affected smallholder farmer's access to credit sources offered by banks in the Capricorn District Municipality of Limpopo Province, South Africa.

The study also revealed that education has significant influence on smallholder farmers' access to bank credit. Having a higher level of education increases the odds in favor of access to bank credit by a factor of 26r. This could be attributed to high degree of financial literacy as the more educated the smallholder farmer is, the more skills and knowledge is attained in management and financial matters. These findings are consistent with that of Dzadze et al., (2012) and Obisesan (2013) who also found that education is a significant determinant of smallholder farmers' credit access.

Gender was also one of the variables found to be significant at 10\% confidence interval. It was expected that male smallholder farmers had more access to bank credit than their female counterparts. Contrary however, the study revealed that female smallholder farmers $(64.30 \%)$ had more access to bank credit in comparison to their male counterparts $(35.70 \%)$. However, this result should be read with caution because the significant effect could be attributed to the overrepresentation of female in our sample compared to male as shown in Table 3. Also, another possible reason for this result could be that the majority of women who responded to our study have more access to various types of financial information than their male counterpart.

The rest of the variables identified in the study didn't appear to have any significant influence on the probability of having access to bank credit as indicated by insignificant p-value. This finding suggests that distance to a bank, farm size, farm experience, income from farming activities, marital status, interest rate and lending procedures had no significant influence on the probability of smallholder famers having access to bank credit. With regard to income from farming activities, it was expected that a higher level of income from farming activities implied the ability of a smallholder farmer to repay the principal and the interest owed to the bank. However, it was found that currently, despite the fact that $53 \cdot 3 \%$ of smallholder farmers with access to bank credit earned over 2 million Tanzanian Shilling annually, $86 \%$ of them secured loans against their salaries imply- 
ing that the repayment of the principal and interest was guaranteed. As a result, income from farming activities did not significantly influence access to bank credit.

Farm size and farming experience were also found to be not significant in influencing access to bank credit by smallholder farmers. These two variables were associated to the age of the smallholder farmer. The older the smallholder farmer becomes, the more experience gained however, the smaller was the number of acres cultivated. Only $7.4 \%$ of the sampled smallholder farmers were below 25 years old, while $63 \%$ were above 35 years old. Farming experience had an insignificant influence on accessibility to bank credit as sampled smallholder farmers lacked modern farming skills thus, the experience they possess does not count as it originates from traditional subsistence farming and therefore lacks impact on bank credit accessibility.

\begin{tabular}{|c|c|c|c|c|}
\hline Variable & B & Wald & Sig. & $\operatorname{Exp}(B)$ \\
\hline Gender & -5.365 & 2.986 & $.084^{\star \star \star}$ & .005 \\
\hline Education & $5 \cdot 562$ & 3.799 & $.050^{\star \star}$ & 260.542 \\
\hline Distance to a bank [Proximity] & I.39I & $.9 \mathrm{II}$ & .340 & 4.020 \\
\hline Farm Size & -.666 & .044 & .833 & .514 \\
\hline Farming Experience & -3.790 & I. 875 & $.17 \mathrm{I}$ & .023 \\
\hline Value of Assets invested in farming activities & 3.190 & $6.6 \mathrm{II}$ & $.010^{\star}$ & 22.396 \\
\hline Income from farming activities & 15.068 & $.7 \mathrm{II}$ & .399 & 3497533.589 \\
\hline Marital Status & .049 & $.00 I$ & .977 & 1.050 \\
\hline Interest rate & 19.423 & .000 & .996 & 272401545.567 \\
\hline Lending Procedures [Procedures] & I2.567 & .000 & .998 & 286824.269 \\
\hline Collateral & 9.294 & .000 & .999 & .000 \\
\hline Constant & 54.572 & .000 & .996 & .000 \\
\hline
\end{tabular}

$\star \star \star \star$ Significant at $\mathrm{I} \% ;{ }^{\star \star}$ Significant at $5 \%$; ${ }^{\star}$ Significant at I0\%

Table 5: Results of Logit Analysis on Bank Credit Accessibility.

\section{Summary and conclusions}

The main purpose of this study was to determine the factors influencing access of smallholder farmers to bank credit. The data used in this research were based on survey data collected from 162 smallholder farmers in Mvomero District, Morogoro, Tanzania. In this study, the determinants of access to bank credit by smallholder farmers were analysed using the logit regression model because the dependent variable, having access to bank credit, is a categorical variable with two possible outcomes. The results show that access to bank credit is largely determined by the value of assets invested in farming activities, gender and education of the smallholder farmers. This study contributes to existing knowledge by showing that value of assets invested in farming activities, gender, and education significantly explain the probability of smallholder farmer having access to bank credit. Furthermore, one of the findings of this study is that the value of assets in- 
vested in farming activities has a significant relationship with access to bank credit. Thus, this study suggests a valid loan selection criterion should include value of assets invested in farming activities. Secondly, it was found that the level of education of the smallholder famers increases the probability of getting access to bank credit. Therefore, policy makers and all organizations that have a stake in the agricultural sector should support the education and training of smallholder famers to develop their education skills. Moreover, smallholder farmers should shift from subsistence to commercial farming to exploit the full potential of bank financing and join cooperative unions to increase their accessibility to bank credit and reduce the burden of repayment. Furthermore, the study recommends that banks should develop special financial products such as loans that cater to the needs of smallholder farmers and establish several branches or agencies in rural areas, and conduct a number of colloquia that will enhance farmers' financial literacy.

It should be noted that while this study provides some insight into the factors influencing access of smallholder farmers to bank credit, there are several limitations that should be considered when interpreting the results. First, the findings of this study were based on the data collected from only one business sector, thus we do not know how applicable these findings might be to businesses in other sectors. Therefore, future research should include businesses in other sectors to ascertain if the present findings are specific to the agriculture business only or if they are applicable to other businesses as well. Secondly, the sample was selected from one district out of the 26 regions in Tanzania. Even though the descriptive statistics indicate that the sample is likely to represent smallholder farmers in Tanzania generally, there is some potential for bias in the results. Future research that examines the factors influencing access of smallholder farmers to bank credit, should also consider other regions. Thirdly, this study found that female smallholder farmers had more access to bank credit than male smallholder farmers. The reason for this disparity is not clear. Future research is needed to look at the relationship between gender and the access to bank credit to smallholding farmers.

\section{References}

Auma, D. and Mensah, P. (2014). Determinants ofCredit Access and Demand among Small-holder Farmers in Tigray Region, Ethiopia. Unpublished Master's Thesis. Norwegian University of Life Sciences, School of Economics and Business.

Akudugu, M. A. (2012). Estimation of the Determinants of Credit Demand by Farmers and Supply by Rural Banks in Ghana's Upper East Region. Asian Journal of Agriculture and Rural Development, 2(2), 189-200.

Bee, F. K. (2007). "Rural Financial Markets in Tanzania: An Analysis of Access to Rural Financial Markets in Babati District, ManyaraRegion." PhD Thesis, University of South Africa.

Chauke, P. K., Motlhatlhana, M. L. Pfumayaramba, T. K. and Anim, F. D. K. (20I3). Factors Influencing Access to Credit: A Case Study of Smallholder Farmers in the Capricorn District of South Africa. African Journal of Agricultural Research, 8(7), 582-585.

Coates, M., Kitchen, R., Kebbell, G., Vignon, C. Guillemain, C. and Hofmeister, R. (20II). Financing Agricultural Value Chains in Africa:Focus on Pineapples, Cashews and Cocoa in Ghana. Deutsche Gesellschaft für Internationale Zusammenarbeit (GIZ) GmbH. 
Dzadze P., Osei M. J., Aidoo R. and Nurah G. K. (2012). Factors Determining Access to Formal Credit in Ghana: A case Study of Smallholder Farmers in the Abura-Asebu Kwamankese District of Central Region of Ghana. Journal of Development and Agricultural Economics, 4(I4), 416-423.

Gaisina, S (2010). Access to Bank Credit by Agricultural Producers in Kazakhstan: a Micro-Econometric Analysis. The International Journal of Economic Policy Studies, 5(3), 33-48.

InfoDev (2012). The Agribusiness Innovation Center of Tanzania Scaling Value Adding, Post-Harvest Processing Agribusinesses.infoDev, Finance and Private Sector Development Department. Washington, DC: World Bank.

Jari, B. (2009). Institutional and Technical Factors Influencing Agricultural Marketing Channel Choices amongst Smallholder and Emerging Farmers in the Kat River Valley. Unpublished Master's Thesis, University of Fort Hare.

Kimathi, M., Nandazi, M., Miller, C. and Kipsang, D. (2008). Africa Agricultural Value Chain Financing: $3^{\text {rd }}$ AFRACA Agribanks forum Synthesis report. African Rural and Agricultural Credit Association and Food and Agriculture Organization.

Louw, A. Nhemachena, C and Zyl, S. (2008). Agribusiness Linkages in the Southern African Region: Small Farmer participation. Regoverning Markets, Policy Brief 2.http://web.up.ac.za/sitefiles /file/48/2052/3_\%20 Agribusiness\%20Linkages\%20in\%20SADC.pdf accessed on January 25 th, 2016.

MAFAP (2013). Review of Food and Agricultural Policies in the United Republic of Tanzania. MAFAP Country Report Series, FAO, Rome, Italy.

Mbunda, R. (20II). Kilimo Kwanza and Small Scale Producers: An Opportunity or a Curse? Land Rights Research and Resources Institute in Tanzania.

Miller, C., Richter, S., McNellis, P. and Mhlanga, N. (2010). Agricultural Investment Funds for Developing Countries. Food and Agriculture Organization of the United Nations.

http://www.fao.org/fileadmin/user_upload/ags/publications/ investment_funds.pdf accessed January 22nd, 2016.

Morris G. A. and Meyer R. L. (1993). Women and financial services in developing countries: a review of the literature. Economics and Sociology. Occasional Paper.

Mukiri, W. (2008). Determinants of Access to Bank Credit by Micro and Small Enterprises in Kenya, Growing Inclusive Markets Conference.

Nawai, N. and Shariff, M. (2010). Determinants of Repayment Performance in Microcredit Programs: A Review of Literature. International Journal of Business and Social Science, I(2), I52-I6I.

Obisesan, A. A. (2013). Credit Accessibility and Poverty among Smallholder Cassava Farming Households in South West, Nigeria. Greener.Journal of Agricultural Sciences, 3 (2).

Organization of Economic Cooperation and Development (2004). Financing SMEs and Entrepreneurs. Policy Brief, November 2004. Retrieved from www.oecd.org/publications/Policybriefs accessed on March I4th, 2016.

_ (2006). The SME financing gap volume 1 theory and evidence. Retrieved from http://www.insine.org/documenti/sme_financing_gap_oced.pdf accessed on April o7th, 2016. (2013). Improving Access to Finance in Kazakhstan's Agribusiness Sector. Kazakhstan Sector Competitiveness Strategy Phase II. Private Sector Development Policy Handbook.

Salami, A., Kabyemera, J and John Anyanwu, J. (20II) Smallholder Agriculture in Africa's Changing Economy: Case Studies.

United Republic of Tanzania (2008). Small Farmer Productivity through Increased Access to Draught Power Opportunities. Stakeholder mapping in Morogoro region, Consultancy Report. MOVEK Development Solution.

Wattanapruttipaisan, T. (2003). Four Proposals for Improved Financing of SME Development in Asean. Asian Development Review, 20 (2).

Wolter, D. (2010). Tanzania - Why a Potential Food Exporter is Still Importing Food. OECD Development Centre, Paris. http://www.oecd.org/dev/41302291.pdf 
World Bank (2013) Growing Africa: Unlocking the Potential of Agribusiness

http://siteresources.worldbank.org/INTAFRICA/Resources/africa-agribusiness-report-2013.pdf

Yehuala S (2008). Determinants of Smallholder Farmers Access to Formal Credit. A case of Metema Woreda, North Gonder, Ethiopia. Unpublished Master's Thesis. Haramaya University, Ethiopia. 